\title{
COMPARISON OF THE ANTIOXIDANT ACTIVITY, PHYTOCHEMICAL AND NUTRITIONAL CONTENTS OF TWO ANTIHYPERTENSIVE ETHNOMEDICINAL PLANTS
}

\author{
*Gbadamosi, I.T and Kalejaye, A.O. \\ Department of Botany, University of Ibadan, Ibadan, Nigeria. \\ *Corresponding author address: gita4me2004@yahoo.com \\ (Received: 3rd March, 2016; Accepted: $8^{\text {th }}$ July, 2017)
}

ABSTRACT

\begin{abstract}
The fruits of Xylopia aethiopica (Dunal) A. Rich and leaves of Persea americana (Mill.) are ethnomedicinally used in combination (1:10) as a remedy for the treatment of hypertension in southwest Nigeria. This study compared the antiradical activity, phytochemical and proximate components of the two plants, with a view to providing scientific information on the therapeutic properties and potential of the plants. The antioxidant activity of the samples was against 1,1-diphenyl-2-picrylhydrazyl (DPPH) radicals. The phytochemical and proximate analyses were carried out using standard laboratory techniques. The plants showed varied antioxidant activity. $X$. aethiopica had $39.10 \mathrm{mg}$ GAE/g polyphenol content and gave $67.43 \%$ inhibition against $\mathrm{DPPH}^{+}$whereas $P$. americana with $24.3 \mathrm{mg}$ GAE/g polyphenol content had 48.3\% inhibition against $\mathrm{DPPH}^{+}$. It was observed that there was direct relationship between polyphenol content and antioxidant activity of the plants. There were also significant variations in the chemical components of the plants. Quantitative phytochemical screening showed that alkaloids (1483.33 mg/100g), proanthocyanidins (16.17mg GAE/g), tannins (968.33 mg/100g) and anthraquinones $(58.3 \mathrm{mg} / 100 \mathrm{~g})$ were higher in $X$. aethiopica than in $P$. americana. On the other hand, P. americana contained more flavonoids $(777.67 \mathrm{mg} / 100 \mathrm{~g})$, cardiac glycosides $(41.67 \mathrm{mg} / 100 \mathrm{~g})$ and saponins $(610 \mathrm{mg} / 100 \mathrm{~g})$ than $X$. aethiopica. X. aethiopica was richer in ash $(4.47 \%)$, fats $(22.43 \%)$, crude fibre $(12.47 \%)$, moisture content $(10.23 \%)$ and energy $(2716.30 \mathrm{Kcal})$ than P. americana. However, $P$. americana had higher contents of crude protein $(21.57 \%)$ and carbohydrates $(50.73 \%)$. The observed antioxidant activity and chemical components of the two plants might be responsible for their therapeutic use as antihypertensive remedy.
\end{abstract}

Keywords: Xylopia aethiopica, Persea americana, Antioxidant activity, Phytochemical components, nutritional contents

\section{INTRODUCTION}

$X$. aethiopica, commonly called Ethiopian/African pepper is locally known as "Eeru-alamo" among Yoruba people of southwest Nigeria (Figure. 1). It is an evergreen, aromatic tree, of the Annonaceae family that can grow up to $20 \mathrm{~m}$ high. It is a native to the lowland rainforest and moist fringe forests in the savanna zones of Africa (Orwa et al. 2009; Burkill, 1985). It is an important spice in the preparation of several delicacies, and also used traditionally in the management of several diseases in Nigeria (Mann, 2011).

P. americana known as Avocado is called "Ubeoyinbo" (Igbo) or "Pia" (Yoruba) in Nigeria (Figure. 2). It belongs to family Lauraceae. P. americana is a medium to large tree, $9-20 \mathrm{~m}$ in height. The avocado is an evergreen tree with canopy ranges from low, dense, and symmetrical to upright and asymmetrical (Anon, 1986). Leaves and seed cotyledon are used in the management of hypertension and other diseases in Nigeria (Gill,
1992; Lawal et al., 2009).

A decoction of the fruits of $X$. aethiopica and leaves of $P$. americana is used in combination $(1: 10)$ as antihypertensive remedy in southwest Nigeria. In addition, $X$. aethiopica and $P$. americana have been reported to possess an array of bioactivities and pharmacological effects such as antimicrobial, anti-inflammatory, hypolipidaemia and hepatoreparative/hepatoprotective effects (Erhirhie and Moke, 2014; Yasir et al., 2010). The hypotensive effect of $X$. aethiopica fruit and $P$. americana leaf as a recipe has been reported by Gbadamosi et al. (2016).

Oxidative stress as caused by generation of free radical has been implicated in the pathogenesis of many degenerative diseases such as hypertension, diabetes, strokes, cancer, and neurodegenerative diseases (Uttara et al., 2009). In order to alleviate this menace of oxidative stress, the body naturally synthesizes antioxidants and enzymes with 
antioxidant activities such as superoxide dismutase (SOD), catalase (CAT), Glutathione (GSH) and Nitric oxide (NO) whose primary role is to deactivate reactive oxygen species (ROS) (Bharti and Srivastava, 2009). Chemically synthesized antioxidants such as butylated hydroxyanisole (BHA), butylated hydroxytoluene (BHT), tertiary butyl hydroquinone (TBHQ) are often added to food as preservative to prevent lipid peroxidation (Venkatesh and Sood, 2011). The DPPH assay is reportedly one of the most widely and effective methods for screening antioxidant activities of samples. It allows testing of both lipophilic and hydrophilic compounds (Koleva et al., 2002). In a DPPH radical scavenging assay, BHA has antioxidant ability of about $64 \%$ whereas BHT has about 49\% (Katalinic et al., 2004). Kahl and Kappus (1993) reported toxic effect of chemically synthesized antioxidants such as BHT and BHA. Their toxic effects include impairment of blood clotting and tumour promoting effect. Specifically, BHA causes tumour in the fore stomach while BHT causes tumour in lungs and liver (Karl and Kappus, 1993). On the other hand, plants polyphenols might serve as antioxidant to 'mop up' these free reactive oxygen species (ROS) with no side effects (Pandy and Rizvi, 2009). Antioxidants of plant origin could have great importance in prevention and treatment of several diseases associated with oxidative stress (Krishnaiah and Sarbatly, 2007).

The presence of phytochemicals in plants lends scientific credence to their ethnomedicinal uses in the treatment of several degenerative disorders. Alkaloids have been reported to have wide range of biological activities such as emetic, diuretic, antidepressant, antihypertensive, antimicrobial and anti-inflammatory among other (Abulude, 2007). Flavonoids are known to be bactericidal, pesticidal and fungicidal in nature ( $\mathrm{El}$ astal et al., 2005). According to Dharmanda (2003), tannins in plants are known to be astringents, which help in wound healing. Usman and Usuji (2007) reported that they are used for treating intestinal disorders such as diarrhea and dysentery.

Anderson et al. (2009) reported that individuals with high intakes of dietary fiber have significant lower risk for developing coronary heart diseases, stroke, hypertension, diabetes, obesity and certain gastrointestinal diseases. Also, increasing fiber intake lowers blood pressure and serum cholesterol levels. Increased fibre content in the body of organisms could reduce incidence of diseases like diabetes, high blood pressure, piles, digestive disorders (SACN, 2008). Apart from insulating and conserving body temperature in organisms, fatty acid components such as lauric acid in $P$. americana, have been reported to improve health (Fite, 2000). The impact of proteins in body system cannot be over looked. They repair and replace worn out cells, form structural and globular materials that hold the body, form blood proteins, and boost the immune system (Olusanya, 2008). Hofman et al. (2002) reported that ash content is generally recognized as measure of quality for the assessment of functional properties of foods. Ash constituents of the investigated samples could be related to their mineral contents and these minerals, which are mostly in forms of chemical compounds, play numerous functions towards the improvement of health in the body of organisms (Onwuka, 2005). Carbohydrates are related to energy generation (Olusanya, 2008).

In view of the reported ethnomedicinal values of the two test plants, this study investigates antioxidant activity, phytochemical and proximate composition of $X$. aethiopica and $P$. americana to provide an empirical basis or justification for their use as antihypertensive ethnomedicinal plants.

\section{MATERIALS AND METHODS}

\section{Collection and Identification of Plants}

Dried fruits of Xylopia aethiopica (UIH-22458) and leaves of Persea americana (UIH-22459) were collected from University of Ibadan campus. Voucher specimens were deposited at the University of Ibadan Herbarium (UIH) for reference purpose.

\section{Preparation of Plant Materials}

The plants were cut into smaller pieces or macerated and air-dried for two weeks at room temperature $\left(25-30{ }^{\circ} \mathrm{C}\right)$. The dried plants were then ground into powder and stored in air-tight glass containers prior to their use in experiments.

\section{Reagents}

Ethanol, sodium acetate, vanillin, methanol, 
potassium ferrocyanide, standard tannic acid, acetic acid, ammonium hydroxide, diethyl ether, benzene, $n$ - butanol, standard anthraquinone, 2,2bipyridine, ferric ammonium sulphate, ferric chloride, concentrated tetraoxosulphate VI acid glacial acetic acid, acetone, sodium chloride, ethanol, ammonia, 1,1-diphenyl2-picrylhydrazyl (DPPH) solution, zinc dust.

\section{In Vitro Antioxidant Assay}

The method of Brand-Williams et al. (1995) was used to determine antioxidant activity via DPPH (1, 1-diphenyl-2-picrylhydrazyl) assay. DPPH $\left(20 \mathrm{mg} / \mathrm{dm}^{3}\right)$ was prepared in $80 \%$ methanol. 0.2 $\mathrm{mg}$ of extract of sample was added to $2.8 \mathrm{ml}$ of DPPH solution. The mixture was incubated for 20 min in dark room at room temperature $\left(25-30^{\circ} \mathrm{C}\right)$ and the absorbance was read at $517 \mathrm{~nm}$ using a spectrophotometer. Methanol only was used as a blank to adjust the spectrophotometer to zero absorbance and DPPH solution was used as the control. The scavenging activity of each extract was calculated as follows:

$\%$ Inhibition $=\left[1-\left(\mathrm{A}^{\text {sample }} / \mathrm{A}^{\text {control }}\right)\right] \times 100$

where $A^{\text {control }}$ is the absorbance for control and $A$ sample is absorbance for test sample.

\section{Phytochemical Analysis}

The samples were analysed for the presence of alkaloids, anthraquinones, cardiac glycosides, flavonoids, phytates, polyphenols, proanthocyanidins, saponins and tannins.

\begin{abstract}
Alkaloids
The method of Harborne (2005) was used for the analysis of alkaloids in samples. $200 \mathrm{ml}$ of $10 \%$ acetic acid in ethanol was added to $5.0 \mathrm{~g}$ of powdered sample in $250 \mathrm{ml}$ beaker. The mixture was covered and allowed to stand for $4 \mathrm{~h}$. The mixture was filtered and the filtrate was concentrated on a water bath to one-fourth of its original volume, concentrated ammonium hydroxide $\left(\mathrm{NH}_{4} \mathrm{OH}\right)$ was added drop wise to the extract until precipitation was completed and the solution was allowed to settle. The precipitate collected was washed with dilute $\mathrm{NH}_{4} \mathrm{OH}$ and then filtered. The residue was dried and weighed. The alkaloid content was calculated using the formula: $\%$ alkaloid $=$ Final weight of the sample / Initial weight of the extract $\mathrm{x}$ 100. The
\end{abstract}

experiment was replicated three times. The result was expressed as $\mathrm{mg} / 100 \mathrm{~g}$.

\section{Anthraquinones}

Benzene $(60 \mathrm{ml})$ was added to $0.5 \mathrm{~g}$ of sample in a beaker and stirred. The mixture was filtered into $100 \mathrm{ml}$ volumetric flask. $0.2 \%$ zinc dust and $59 \mathrm{ml}$ of hot $5 \% \mathrm{NaOH}$ solution were added. The mixture was heated just below boiling point for $5 \mathrm{mins}$ and rapidly filtered. This was then washed once in water. The filtrate was heated again with another $50 \mathrm{ml}$ of $5 \% \mathrm{NaOH}$ to develop a red colour. Standards were then prepared from 100 $\mathrm{mg} / \mathrm{L}$ stock and treated in a similar way with $0.2 \%$ zinc dust and $\mathrm{NaOH}$. Absorbance was read at $640 \mathrm{~nm}$ (Harborne, 2005). The result was expressed as $\mathrm{mg} / 100 \mathrm{~g}$.

\section{Cardiac Glycosides}

Water $(40 \mathrm{ml})$ was added to $1 \mathrm{~g}$ of sample. The mixture was placed in oven at $100^{\circ} \mathrm{C}$ for $15 \mathrm{mins}$ and then filtered. To $1 \mathrm{ml}$ of the filtrate, $5 \mathrm{ml}$ of water and $2 \mathrm{ml}$ of glacial acetic acid were added. 1 drop of $\mathrm{FeCl}_{3}$ and $1 \mathrm{ml}$ of concentrated $\mathrm{H}_{2} \mathrm{SO}_{4}$ were then added to the mixture (Harborne, 2005). The absorbance of the mixture was read at $410 \mathrm{~nm}$ using spectrophotometer and the result was expressed as $\mathrm{mg} / 100 \mathrm{~g}$.

\section{Phytates}

One gram (1 g) of the sample was extracted with $0.2 \mathrm{M} \mathrm{HCl} . \mathrm{Fe}^{3+}$ solution was added to $0.5 \mathrm{ml}$ of the extract. The mixture was heated in a water bath for 30 mins, cooled and then centrifuged. $1.5 \mathrm{ml}$ of 2, 2-bipyridine solution was then added to $1 \mathrm{ml}$ of the supernatant. Absorbance was read at 519 $\mathrm{nm}$ using distilled water as blank (Harborne, 2005). The result was expressed as $\mathrm{mg} / 100 \mathrm{~g}$.

\section{Flavonoids}

The method of Ordon Ez et al, (2006) was used for the flavonoids analysis of the samples. The sample $(0.5 \mathrm{ml})$ was added to $0.5 \mathrm{ml}$ of $2 \% \mathrm{AlCl}_{3}$ ethanol solution. The mixture was allowed to stand for $1 \mathrm{~h}$ at room temperature and a yellow color indicated the presence of flavonoids. The absorbance was read at $420 \mathrm{~nm}$. The samples were evaluated at a final concentration of $0.1 \mathrm{mg} / \mathrm{ml}$. The result was expressed as $\mathrm{mg} / \mathrm{g}$ using the equation: $\mathrm{Y}=$ $0.0255 \mathrm{x}, \mathrm{R} 2=09312$, where $\mathrm{x}$ is the absorbance and $\mathrm{Y}$ is the quercetin equivalent. The experiment 
was replicated three times. The result was expressed as $\mathrm{mg} / 100 \mathrm{~g}$.

\section{Polyphenols}

An aliquot of the extract was mixed with $5 \mathrm{ml}$ of Folin-Ciocalteu's reagent (previously diluted with water at a concentration of $1: 10 \mathrm{v} / \mathrm{v}$ ) and $4 \mathrm{ml}$ of $75 \mathrm{~g} / \mathrm{L}$ of sodium carbonate in a test tube. The mixture was vortexed for $15 \mathrm{~s}$ and left to stand for $30 \mathrm{~min}$ at $40{ }^{\circ} \mathrm{C}$ for color development. The absorbance was read at $765 \mathrm{~nm}$ using spectrophotometer (Wolfe et al., 2003). The results were expressed as $\mathrm{mg} / \mathrm{g}$ of tannic acid equivalent using the calibration curve: $\mathrm{Y}=0.121 \mathrm{x}, \mathrm{R} 2$ $=0.936512$, where $\mathrm{x}$ is the absorbance and $\mathrm{Y}$ is the tannic acid equivalent. The experiment was replicated three times. The result was expressed as $\mathrm{mg} / 100 \mathrm{~g}$.

\section{Proanthocyanidins}

The extract $(0.5 \mathrm{ml}$ of $1 \mathrm{mg} / \mathrm{ml})$ solution was mixed with $3 \mathrm{ml}$ of vanillin-methanol $(4 \% \mathrm{v} / \mathrm{v})$ and $1.5 \mathrm{ml}$ of hydrochloric acid. The mixture was left for $15 \mathrm{~min}$ at room temperature and the absorbance was read at 500nm (Sun et al., 1998). The result was expressed as catechin equivalent $(\mathrm{mg} / \mathrm{g})$ using the calibration curve equation: $\mathrm{Y}=$ $0.5825 \mathrm{x}, \mathrm{R} 2=0.9277$, where $\mathrm{x}$ is the absorbance and $\mathrm{Y}$ is the quercetin equivalent. The experiment was replicated three times. The result was expressed as $\mathrm{mg} / 100 \mathrm{~g}$.

\section{Saponins}

The powdered sample $(20 \mathrm{~g})$ was added to $100 \mathrm{ml}$ of $20 \%$ aqueous ethanol and kept on a shaker for $30 \mathrm{~min}$. The sample was heated on a water bath for $4 \mathrm{~h}$ at $55^{\circ} \mathrm{C}$. The mixture was filtered and the residue re-extracted with another $200 \mathrm{ml}$ of $20 \%$ aqueous ethanol. The combined extracts were reduced to approximately $40 \mathrm{ml}$ on a water bath at $90^{\circ} \mathrm{C}$. The concentrate was transferred into a 250 $\mathrm{ml}$ separating funnel and extracted twice with 20 $\mathrm{ml}$ diethyl ether. The ether layer was discarded while the aqueous layer was retained and to which $60 \mathrm{ml}$ n-butanol was added. Then n-butanol extract was washed twice with $10 \mathrm{ml}$ of $5 \%$ aqueous sodium chloride $(\mathrm{NaCl})$. The remaining solution was heated on a water bath. After evaporation, the sample was dried in the oven at $40^{\circ} \mathrm{C}$ to a constant weight (Harborne, 2005). The saponin content was calculated and expressed as $\mathrm{mg} / 100 \mathrm{~g}$.

\section{Tannins}

The sample $(0.20 \mathrm{~g})$ was added to $20 \mathrm{ml}$ of $50 \%$ methanol. The mixture was shaken thoroughly and placed in a water bath at $80^{\circ} \mathrm{C}$ for $1 \mathrm{~h}$ to ensure uniform mixing. The mixture was filtered into a $100 \mathrm{ml}$ volumetric flask, followed by the addition of $20 \mathrm{ml}$ of distilled water, $2.5 \mathrm{ml}$ of Folin-Denis reagent and $10 \mathrm{ml}$ of $17 \%$ aq. $\mathrm{Na}_{2} \mathrm{CO}_{3}$. The solution was thoroughly mixed. The mixture was made up to $100 \mathrm{ml}$ with distilled water, mixed and allowed to stand for $20 \mathrm{~min}$. The bluish-green color developed from the reaction mixture of different concentrations (0-10ppm). The absorbance of the tannic acid standard solutions as well as sample was read at $760 \mathrm{~nm}$ using the spectrophotometer (Harborne, 2005). The results were expressed as $\mathrm{mg} / \mathrm{g}$ of tannic acid equivalent using the calibration curve: $\mathrm{Y}=0.0593 \mathrm{x}-0.0485$, $\mathrm{R} 2=0.9826$, where $\mathrm{x}$ is the absorbance and $\mathrm{Y}$ is the tannic acid equivalent. The experiment was replicated three times. The result was expressed as $\mathrm{mg} / 100 \mathrm{~g}$.

\section{Proximate Analysis}

The carbohydrate, crude fibre, crude protein, fat, moisture, total ash contents and energy values of samples were analysed using standard protocols (AOAC, 2006; Horwitz, 2000; Greenfield and Southgate, 1992; ASEAN, 2011) in the Laboratory of the Department of Animal Science, Faculty of Agriculture and Forestry, University of Ibadan, Nigeria.

Determination of moisture content: The airoven method was used for the evaluation of moisture content of samples. Crucible was washed and dried in an oven at $100 \pm 5^{\circ} \mathrm{C}$ until constant weight $(1-2 \mathrm{~h})$. The crucible was allowed to cool in the desiccator for $30 \mathrm{~min}$ and weighed $\left(\mathrm{W}_{1}\right)$. The thoroughly mixed sample $(4 \mathrm{~g})$ was transferred into the pre-weighed crucible. The weight of the sample and crucible was taken before drying $\left(\mathrm{W}_{2}\right)$. The crucible with sample was placed in the air oven preheated to $100 \pm 5^{\circ} \mathrm{C}$ for 2-3 h. The crucible with dry sample was transferred into the desiccator and allowed to cool for $30 \mathrm{~min}$ and weighed $\left(\mathrm{W}_{3}\right)$. The procedure was repeated until constant weight was obtained. The moisture content was calculated as follows: 
$\%$ Moisture content $=\left(\mathrm{W}_{2}, \mathrm{~W}_{3}\right) /\left(\mathrm{W}_{2}, \mathrm{~W}_{1}\right) \times 100$.

Determination of ash content: The gravimetric method was used for the quantitative determination of ash in samples. The crucible was heated in the furnace at $500-550{ }^{\circ} \mathrm{C}$ for $2-3 \mathrm{~h}$. The temperature was reduced to $180^{\circ} \mathrm{C}$ and the crucible was transferred into a desiccator, cooled for $30 \mathrm{~min}$ and weighed $\left(\mathrm{W}_{1}\right)$. $4 \mathrm{~g}$ of sample was transferred into the pre-weighed crucible $\left(\mathrm{W}_{2}\right)$. The sample was charred over a hotplate, initially at low temperature to avoid spattering, the temperature was gradually increased until smoking ceased. The charred sample was incinerated in a furnace at $500-550{ }^{\circ} \mathrm{C}$ until the residue was uniformly white or neatly white, the temperature was reduced to $180^{\circ} \mathrm{C}$ and the sample was allowed to cool in a desiccator for $30 \mathrm{~min}$, and weighed $\left(\mathrm{W}_{3}\right)$. The ash content was calculated as follows:

$\%$ Ash content $=\left(\mathrm{W}_{3}, \mathrm{~W}_{1}\right) /\left(\mathrm{W}_{2}-\mathrm{W}_{1}\right) \times 100$.

Determination of crude fat: The Soxhlet's extraction method was used. The sample $(5 \mathrm{~g})$ was measured into a weighed filter paper and folded neatly; this was put inside pre-weighed thimble $\left(\mathrm{W}_{1}\right)$. The thimble with the sample $\left(\mathrm{W}_{2}\right)$ was inserted into the Soxhlet's apparatus and extraction under reflux was carried out with petroleum ether $\left(40^{\circ} \mathrm{C}-60^{\circ} \mathrm{C}\right.$ boiling range $)$ for 4 $6 \mathrm{~h}$. At the end of extraction, the thimble was dried in the oven for about 30 minutes at $100^{\circ} \mathrm{C}$ to evaporate off the solvent and cooled in a desiccator. It was re-heated and weighed again every 30 min until a constant weight was obtained $\left(\mathrm{W}_{3}\right)$. The percentage fat was calculated as follows:

$$
\% \text { Crude fat }=\left(\mathrm{W}_{2}, \mathrm{~W}_{3}\right) /\left(\mathrm{W}_{2}-\mathrm{W}_{1}\right) \times 100 .
$$

Determination of crude protein: The crude protein content of sample was analysed using Kjeldahl method. The sample $(10 \mathrm{~g})$ was weighed into the digestion tube, $5 \mathrm{~g}$ of catalyst and 1 glass bead to prevent solution from bumping and $10-$ $20 \mathrm{ml}$ of $\mathrm{H}_{2} \mathrm{SO}_{4}$ were added to the sample in the digestion tube. The digestion tube was placed in the digestor and the moisture was digested until the solution became clear and free of carbon. The clear solution was heated for another hour to completely breakdown all organic matter. $500 \mathrm{ml}$ conical flask containing $50 \mathrm{ml}$ of $4 \%$ boric acid with indicator as receiver was placed on the distillation unit. $100 \mathrm{ml}$ of water and $70 \mathrm{ml}$ of 50 $\% \mathrm{NaOH}$ were added to the digests in the distillation set. The distillation of the mixture was done until all ammonia had been released or 150 $\mathrm{ml}$ distillate was obtained. The distilled ammonia was trapped in an ice cold condenser. The receiver flask was lowered so that the delivery tube was above the liquid surface, the distillation continued for $1-2$ min. Finally, the delivery tube was rinsed with water and the washings allowed to drain into the flask. The distillate was titrated with the standardized 0.1 N HCL until the first appearance of the pink colour. The acid used was recorded to the nearest $0.05 \mathrm{ml}$. A blank sample was passed through the same procedure and the titre value for the blank was used to correct the titre for the original sample. The $\%$ crude protein was calculated as follows:

$\%$ Nitrogen $=(\mathrm{ml} 0.1 \mathrm{~N} \mathrm{HCl}$ sample $-\mathrm{ml} 0.1 \mathrm{~N} \mathrm{HCl}$ blank) x 0.0014 x N HCl x 100 / weight of sample. $\%$ Protein $=\%$ total nitrogen $\times 6.25$.

Determination of crude fibre: The total dietary fibre of samples was determined using enzymaticgravimetric method. The method involves enzymatic digestion of dried defatted sample by heat stable alpha-amylase, protease and amyloglucosidase to remove starch and protein present in the sample. Ethanol is then added to the digest to precipitate soluble dietary fibre. $1 \mathrm{~g}$ of sample was defatted in $25 \mathrm{ml}$ of petroleum ether. The sample was digested in $50 \mu \mathrm{L}$ of alpha amylase solution in a beaker. The beaker was placed in shaking water bath at $95^{\circ} \mathrm{C}$ and incubated for $30 \mathrm{mins}$ with continuous agitation. The sample was further digested in protease solution and $5 \mathrm{ml}$ of $0.561 \mathrm{~N} \mathrm{HCl}$ solution while stirring. The $\mathrm{pH}$ of the solution was adjusted to 4.0-4.7 using $1 \mathrm{~N} \mathrm{HCl}$ solution after which $300 \mu \mathrm{L}$ of amyloglucosidase solution was added to the mixture while stirring. The mixture was incubated in shaking water bath with constant agitation at $60^{\circ} \mathrm{C}$ for $30 \mathrm{mins}$. To each digested sample, $225 \mathrm{ml}$ of $95 \%$ ethanol was added and pre-heated at $60^{\circ} \mathrm{C}$. The solution was allowed to stand for $60 \mathrm{~min}$ at room temperature to allow precipitate to form. The mixture was filtered and residue was washed with $78 \%$ ethanol and then transferred into a crucible. The crucible containing residue was put in oven at $100^{\circ} \mathrm{C}$ 
overnight until a constant weight was achieved. The fibre content was expressed as $\%$.

Determination of carbohydrate: The carbohydrate content was calculated as follows: $\% \mathrm{CHO}=100-$ (Sum of the percentages of moisture, ash, fat, protein and crude fibre).

\section{Statistical Analysis}

Analysis of variance and comparison of means was carried out using statistical analysis system (SAS) version 9. Data were expressed as Mean \pm $\mathrm{SD}$. The values lower than 0.05 probability $(p<0.05)$ were accepted as statistically significant by Duncan's Multiple Range Test.

\section{RESULTS}

The anti-radical activity of Xylopia aethiopica and Persea americana against DPPH radical and their polyphenol content are presented in Table 1. X. aethiopica has higher antioxidant activity $(67.43 \%)$ than Persea americana (48.30\%). Also, X. aethiopica contained higher polyphenols (39.10 mg GAE/g) than P. americana (24.30 $\mathrm{mg} \mathrm{GAE} / \mathrm{g}$ ) at $\mathrm{p}<0.05$. Phytochemical screening showed the presence of alkaloids, flavonoids, proanthocyanidins, cardiac glycosides tannins, phytates, anthraquinones and saponins in both plants (Table 2). Alkaloids (1483.33 mg/100g), proanthocyanidins (16.17 mgGAE/g), tannins ( $968.33 \mathrm{mg} / 100 \mathrm{~g})$, phytates $(90.00 \mathrm{mg} / 100 \mathrm{~g})$ and anthraquinones (58.3 $\mathrm{mg} / 100 \mathrm{~g}$ ) were higher in $X$. aethiopica than in $P$. americana. On the other hand, $P$. americana contained more flavonoids (777.67 mg/100g), cardiac glycosides $(41.67 \mathrm{mg} / 100 \mathrm{~g})$ and saponins $(\mathrm{mg} / 100 \mathrm{~g})$ than $X$. aethiopica. Table 3 shows quantitative proximate components of the $X$. aethiopica fruit and $P$. americana leaves. Both samples contained crude ash, fats, crude protein, crude fibre, moisture, carbohydrates and energy but in varied quantity. $X$. aethiopica was richer in ash $(4.47 \%)$, fats $(22.43 \%)$, crude fibre $(12.47 \%)$, moisture content $(10.23 \%)$ and energy $(2716.30 \mathrm{Kcal})$ than $P$. americana. However, $P$. americana had higher contents of crude protein $(21.57 \%)$ and carbohydrates (50.73\%).

Table 1: Polyphenol Component and Antioxidant activities of Xylopia aethiopica and Persea americana

\begin{tabular}{|l|l|l|}
\hline \multicolumn{1}{|c|}{ Parameters } & \multicolumn{2}{|c|}{ Botanicals } \\
\cline { 2 - 3 } & X. aethiopica & P. americana \\
\hline Polyphenols (mg GAE/g) & $39.10 \pm 0.26^{\mathrm{a}}$ & $24.3 \pm 0.21^{\mathrm{b}}$ \\
\hline$\%$ inhibition of $\mathrm{DPPH}^{+}$ & $67.43 \pm 0.15^{\mathrm{a}}$ & $48.30 \pm 0.40^{\mathrm{b}}$ \\
\hline
\end{tabular}

Values expressed as mean \pm S.D; $n=3$. Means with different alphabet across the row are significantly different from each other at $\mathrm{p}<0.05$.

Table 2: Phytochemical components of fruits of Xylopia aethiopica and leaves of Persea americana

\begin{tabular}{|l|l|l|}
\hline \multirow{2}{*}{ Parameters (mg/100g) } & Botanicals \\
\cline { 2 - 3 } & X. aethiopica & P. americana \\
\hline Alkaloids & $1483.3 \pm 16.07^{\mathrm{a}}$ & $760.0 \pm 13.23^{\mathrm{b}}$ \\
\hline Tannins & $968.3 \pm 12.58^{\mathrm{a}}$ & $246.7 \pm 12.58^{\mathrm{b}}$ \\
\hline Cardiac glycosides & $21.7 \pm 5.77^{\mathrm{b}}$ & $41.7 \pm 5.77^{\mathrm{a}}$ \\
\hline Anthraquinones & $58.3 \pm 7.64^{\mathrm{a}}$ & $11.7 \pm 2.89^{\mathrm{b}}$ \\
\hline Flavonoids & $431.7 \pm 10.41^{\mathrm{b}}$ & $776.7 \pm 10.41^{\mathrm{a}}$ \\
\hline Proanthocyanidins & $6.2 \pm 1.26^{\mathrm{a}}$ & $2.8 \pm 0.58^{\mathrm{b}}$ \\
\hline Phytates & $90.0 \pm 5.00^{\mathrm{a}}$ & $51.7 \pm 2.89^{\mathrm{b}}$ \\
\hline Saponins & $341.67 \pm 10.41^{\mathrm{b}}$ & $610 \pm 13.23^{\mathrm{a}}$ \\
\hline
\end{tabular}

Values expressed as mean \pm S.D; $n=3$. Horizontally, means with different a $l \mathrm{phabet}$ a re significantly different from each other at $\mathrm{p}<0.05$. 
Table 3: Proximate composition of Xylopia aethiopica fruit and of Persea americana leaf

\begin{tabular}{|l|l|l|}
\hline \multirow{2}{*}{ Parameters (\%) } & \multicolumn{2}{|c|}{ Botanicals } \\
\cline { 2 - 3 } & X. aethiopica & P. americana \\
\hline Moisture content & $10.2 \pm 0.21^{\mathrm{a}}$ & $9.3 \pm 0.15^{\mathrm{b}}$ \\
\hline Proteins & $19.6 \pm 0.15^{\mathrm{ab}}$ & $21.6 \pm 0.21^{\mathrm{a}}$ \\
\hline Fats & $22.4 \pm 0.21^{\mathrm{a}}$ & $6.5 \pm 0.15^{\mathrm{b}}$ \\
\hline Ash & $4.5 \pm 0.25^{\mathrm{a}}$ & $3.4 \pm 0.15^{\mathrm{b}}$ \\
\hline Crude Fibre & $12.5 \pm 0.15^{\mathrm{a}}$ & $8.5 \pm 0.15^{\mathrm{b}}$ \\
\hline Carbohydrates & $30.8 \pm 0.21^{\mathrm{b}}$ & $50.7 \pm 0.21^{\mathrm{a}}$ \\
\hline Energy (Kcal) & $2716.2 \pm 60.32^{\mathrm{a}}$ & $2299.0 \pm 17.93^{\mathrm{b}}$ \\
\hline
\end{tabular}

Values expressed as mean \pm S.D; $n=3$. Horizontally, me a n s with different alphabet are significantly different from each other at $\mathrm{p}<0.05$.
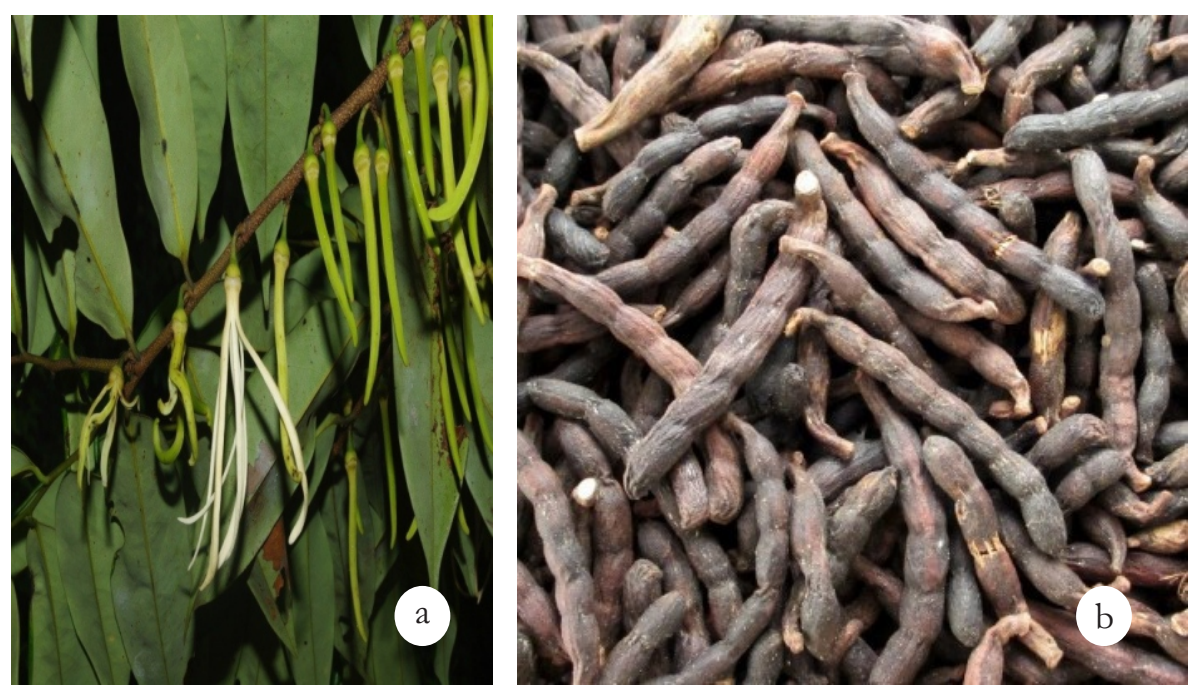

Figure 1: Xylopia aethiopica (Dunal) A. Rich

(a) Leaves and young fruits, (b) Mature fruits
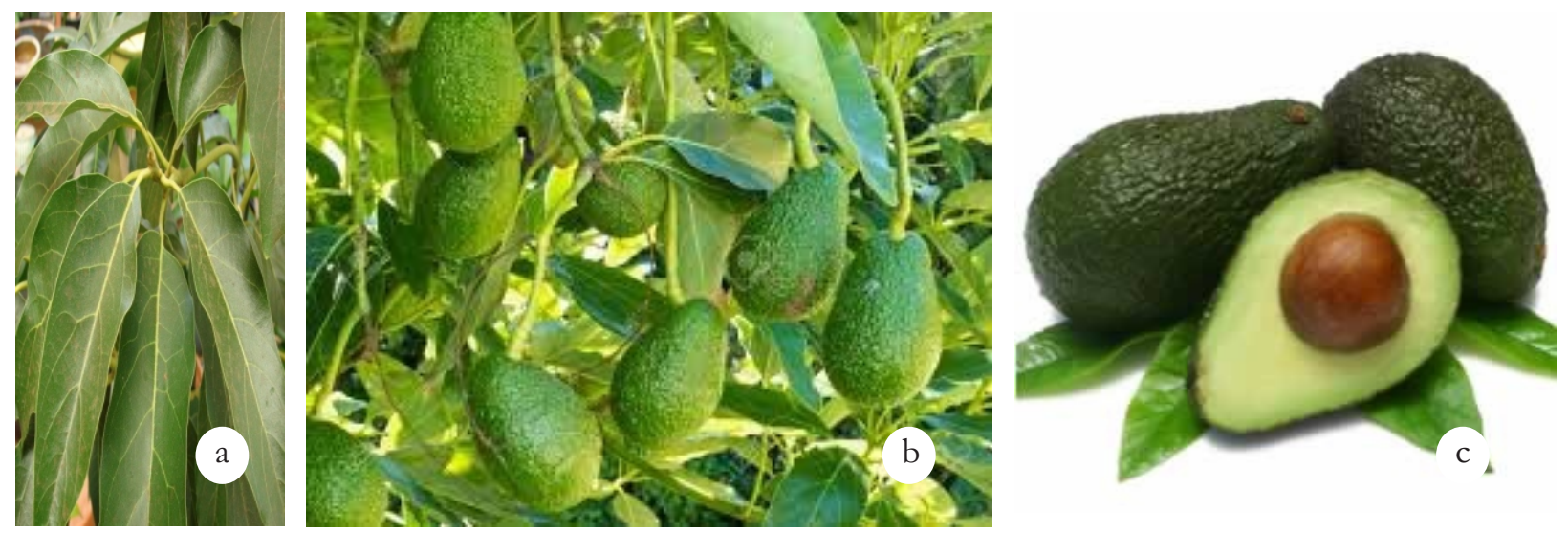

Figure 2: Persea americana Mill.

(a) Leaves, (b) Young fruits, (c) Mature fruits 


\section{DISCUSSION}

The antiradical activity of the extract against $\mathrm{DPPH}^{+}$was observed to be directly proportional to the total phenol content of the two plants. This suggests that the more the phenolic content, the higher the antioxidant activity. It was observed that $X$. aethiopica showed more antioxidant activity $(67.43 \%)$ than P. americana (48.30\%). The higher antioxidant activity displayed by $X$. aethiopica than $P$. americana agrees with the work of Amarowicz et al. (2000) who also reported a positive correlation $(\mathrm{r}=0.966 ; \mathrm{P}=0.002)$ between antioxidant activity and total phenolic content. Tannic acid, a naturally occurring plant polyphenol was reported to exhibit an effective antioxidant activity in six different in vitro antioxidant assays including DPPH radical assay (Gulcin et al., 2009). The antioxidant activity of $X$. aethiopica has been previously reported by Adefegha and Oboh (2012). X. aethiopica showed more antioxidant properties than synthetic antioxidants such as BHT (49\%) and BHA (64\%). Also, X. aethiopica contained significantly higher polyphenols (39.10 $\mathrm{mg} \mathrm{GAE} / \mathrm{g}$ ) and this might be responsible for the higher antioxidant activity observed. Apart from antioxidant potentials, polyphenols have also been shown to have antibacterial, anti-inflammatory, anti-allergic, antiviral antineoplastic activity (Ojiako and Iowe, 2008). The effect of various extraction solvents on antioxidant activity of $P$. americana seed (Adeboyejo et al., 2016) and leaf (Boadi et al., 2015) has been reported. In this study, the antiradical activity displayed by $P$. americana $(48.30 \%)$ is lower than those of $X$. aethiopica $(67.43$ $\%$ ) and BHA (64\%), however, it is comparable with that of synthetic antioxidants such as BHT $(49 \%)$. Furthermore, the little or no side effect of plant derived antioxidants makes them safer in administration compared to synthetic antioxidants that have been reported to be carcinogenic, no matter their low antiradical activities. In literature, there are experimental evidences that reactive oxygen species (ROS) play a major role in the pathophysiology of hypertension. The excessive production of ROS could lead to renal dysfunction and vascular damage (Sinha and Dabla, 2015). Whereas clinical data suggests that antioxidant rich diets reduce blood pressure and cardiovascular risk (Kizhakekuttu and Widlansky, 2010).
The presence of phytochemicals observed in fruits of $X$. aethiopica agrees with the report of previous authors (Okwari et al., 2013; Omeh et al., 2015). P. americana has also been reported to contain many phytochemicals including tannins, flavonoids, terpenoids, and phytosterols (Ross, 1999). Some phytochemicals have been implicated in the antioxidant activity of their plant source by either acting singly or by interacting with polyphenols. For example, Maiza-Benabdesselam et al. (2007) reported the antiradical activity of alkaloids extracts of two Algerian Fumaria spp. against DPPH radical. The alkaloids (Isoquinoline alkaloids, stylopine, protopine, fumaritine, fumaricine, fumarophycine, fumariline and fumarofine) also had effective reducing power and inhibited lipid peroxidation of linoleic acid emulsion (Maiza-Benabdesselam et al. 2007). Amarowicz et al. (2000) reported that crude tannins from canola and rapeseed hull showed significant antioxidant activity $(\mathrm{P}=0.01)$. The antioxidant activity of canola hull crude tannins was significantly $(\mathrm{P} \leqslant 0.025)$ stronger than those of rapeseed due to its higher total phenolics and tannins contents. Pande et al. (2014) reported that saponins and tannins extracted from leaves of Tridax procumbens showed good to moderate antioxidant activity. In this study, X. aethiopica fruit was observed to be richer in phytochemicals than $P$. americana leaf especially polyphenols. Phytochemicals are known to exert their beneficial effects in the management of many chronic diseases such as hypertension by reducing the circulating levels of cholesterol or by inhibiting anti inflammatory and antiplatelet activities (Upadhyay and Dixit, 2015). The health benefits of Dietary Approaches to Stop Hypertension (DASH) are partially attributed to the phytochemicals and might extend beyond cardiovascular disease risk reduction (Most, 2014).

The findings on nutritional components of the two plants are in line with the reports of previous authors (Omeh et al., 2014; Nwaogu et al., 2008; Arukwe et al., 2012). Omeh et al. (2014) reported that the proximate composition of fibre in $X$. aethiopica was $14.51 \%$ which is comparable to $12.47 \%$ reported in this study. This study also revealed that $P$. americana is richer in crude protein $(21.57 \%)$ and carbohydrates $(50.73 \%)$ than $X$. aethiopica. This result agrees with the work of 
Nwaogu et al. (2008) who reported high crude protein $(18.55 \%)$ and carbohydrates $(47.35 \%)$ in the seed extract of $P$. americana. This study also observed that the $\%$ composition of crude protein in leaves $(21.57 \%)$ of P. americana is lower than that of its seed (39.01\%) as reported by Parameswaran and Murthi (2014).Plant protein has been reported to have beneficial effect in the management of blood pressure. A blood pressure lowering effect of protein may have important public health implication (Altorf - van der Kuil, 2010). Of importance is the crude fibre content of $X$. aethiopica reported in this study. Plant fibre is an important part of diet and decreases serum cholesterol level, risk of coronary health disease, hypertension, diabetes, colon and cancer (Liu et al., 1999). The levels of carbohydrates in the investigated samples may indicate that both $X$. aethiopica fruits and $P$. americana leaves would be beneficial in production of energy to power the cells and tissues of the body on consumption (Arukwe et al., 2012). Overall, pharmacological effects of medicinal plants have been attributed to presence of phytochemicals and nutrients in such plants.

\section{CONCLUSION}

Xylopia aethiopica fruits and of Persea americana leaves could be good sources of natural antioxidants due to their significant antiradical activity against DPPH radical observed in this study. The nutritional components could have supplemented the phytochemicals in the antioxidant activity. Furthermore, this study justifies the use of the two plants in ethnomedicine in the management of hypertension by providing scientific information on the phytochemical and nutritional components of samples that could be responsible for the observed antioxidant activity and plausible hypotensive effect.

\section{REFERENCES}

Adeboyebo, O. F., Aderibigbe, R. O. and Ademoyegun, T. O. 2016. Antioxidant effect of Persea americana seed as affected by different extraction solvent. Journal of Advances in Food Science and Technology 3(2):101-106.

Abulude, F. O. 2007. Phytochemical screening and mineral contents of leaves of some
Nigerian woody plants. Research Journal of Phytochemistry 1(1):33-39.

Adefegha, S. A. and Oboh, G. 2012. Effect of diets supplemented with Ethiopian pepper [Xylopia aethiopica (Dun.) A. Rich (Annonaceae)] and Ashanti pepper [Piper guineense Schumach. et Thonn (Piperaceae)] on some biochemical parameters in normal rats. Asian Pacific Journal of Tropical Biomedicine S558-S566.

Altorf - van der Kuil, W, Engberink, M. F., Brink, E. J, van Baak, M. A., Bakker, S. J. L., Navis. G, et al. 2010 Dietary Protein and Blood Pressure: A Systematic Review. PLoS ONE 5(8): e 12102 . https://doi.org/10.1371/journal.pone.0 012102.

Amarowicz, R. Naczk, M. and Shahidi F. 2000. Antioxidant Activity of Crude Tannins of Canola and Rapeseed Hulls. Journal of the American Oil Chemists' Society 77: 957-961.

Anderson, J. W., Baird, P., Richard, H., Davis, J. R., Ferreri, S., Knudtson, M., Koraym, A., Waters, V. and Williams, C. L. 2009. Health benefits of dietary fiber. Nutrition Reviews 67(4):188-205.

Anon 1980. Sweet Potato Quality. In: U.S.D.A. Southern Cooperative Series Bulletin No. 249, Russell Research Centre, Athens, Georgia.

AOAC (Association of Official Analytical Chemist), 2006. Official Methods of Analysis of the AOAC. In: Horwitiz, W. (Ed.). $18^{\text {th }}$ Edition. Association of Official Analytical Chemists, Washington D.C., USA.

Arukwe, U., Amadi, B. A., Duru, M. K. C., Agomuo, E. N., Adindu, E. A., Odika, P. C., Lele, K. C., Egejuru, L. and Anudike, J. 2012. Chemical composition of Persea americana leaf, fruit and seed source. International Journal of Research \& Reviews in Applied Sciences 11 (2): 346-340.

ASEAN Manual of Food Analysis. 2011. Regional Centre of ASEAN Network of Food Data System Institute of Nutrition, $1^{\text {st }}$ Edition. Mahidol University Thailand. Prapasri, P., Tee, E. S., Julia, K., Graham, C., Rafael, R.F. and Kunchit Judprason (Editors) 2011.

Bharti, V. K. and Srivastava, R. S. 2009. Pineal proteins upregulate specific antioxidant 
defense systems in the brain. Oxidative Medicine and CellularLongetivity 2:88-92.

Boadi, N. O., Saah, S. A., Mensah, J. K., Badu, M., Addai-Arhinand, S. and Mensah, B. M. 2015. Phytoconstituents, antimicrobial and antioxidant properties of leaves of Persea americana Mill cultivated in Ghana. Journal of Medicinal Plants Research 36:933939.

Brand-Williams, W., Cuvelier, M.E. and Berset, C. 1995. Use of free radical method to evaluate antioxidant activity. Food Science and Technology 28:25-30.

Burkill, H. M. 1985. The Useful Plants of West tropical Africa, (2 ${ }^{\text {nd }}$ Edition), Royal Botanical Gardens, Kew.

Dharmanda, S. 2003. Gallnuts and the uses of Tannins in Chinese Medicine. In: Proceedings of Institute for Traditional Medicine, Portland, Oregon.

El astal, Z. Y., Aera, A. and Aam, A. 2005. Antimicrobial activity of some medicinal plant extracts in palestine. Pakistan Journal of Medical Science 21(2):187-191.

Erhirhie, E.O. and Moke, G.E. 2014. Xylopia Aethiopica: A Review of its Ethnomedicinal, chemical and pharmacological properties. American Journal PharmTech Research. 4(6): 21-37.

Fite, B. 2000. The Healing miracle of coconut oil. Piccadilly Books Ltd, Healthwise Publications Colorado Springs, Co. 1-4.

Gbadamosi I. T., Kalejaye A. O., Oyagbemi, A. A., Omobowale, T. O. and Ajibade, T. O. 2016. Effects of Xylopia aethiopica fruit and Persea americana leaf extracts on blood pressure changes a n d electrocardiographic disturbances in saltinduced hypertension. Tropical Veterinarian 34(1\&2): 92-104.

Gill, L.S. 1992. Ethnomedical uses of Plants in Nigeria. Uniben Press, University of Benin, Benin City, Edo State, Nigeria. 276p.

Greenfield, H. and Southgate, D. A. T. 1992. Food composition data: Production, Management and Use. Elsevier Applied Science, U.K.

Gulcin I., Huyut, Z., Elmastas, M., and AboulEnein, H. Y. 2009. Radical scavenging and antioxidant activity of tannic acid. Arabian Journal of Chemistry 3: 43-53.
Harborne, J. B. 2005. Phytochemical methods. A guide to modern techniques of plant analysis. $3^{\text {rd }}$ Edition, Springer Pvt. Ltd., New Delhi, India.

Hofman, P. J. Vuthapanich, S. Whiley, A. W. Klieber, A. and Simons, D.H. 2002. Tree yield and fruit minerals concentrations influence "Hass" avocado fruit quality. Science and Horticulture 92: 113-123.

Horwitz, W. 2000. (Editor). Official Method of Analysis of AOAC International. 17th Edition, AOAC International, Maryland, USA.

Kahl, R. and Kappus, H. 1993. Toxicology of the synthetic antioxidants BHA and BHT in comparison with the natural antioxidant vitamin E. Zeitschrift fur LebensmittelUntersuchung und-Forschung 196(4):329-338.

Katalinić, V., Radić, S., Ropac, D., Mulić, R. and Katalinić, A. 2004. Antioxidative activity of propolis from Dalmatia (Croatia). Acta Medical Croatica 58(5):373-376.

Kizhakekuttu, T. J. and Widlansky, M. E. 2010. Natural antioxidants and hypertension: Promise and Challenges. Cardiovascular Therapentics 28(4):e20-e32.

Koleva II, van Beek T. A., Linssen J. P., de Groot A., Evstatieva, L. N. 2002. Screening of plant extracts for antioxidant activity: A comparative study on three testing methods. Phytochemical Analysis 13:8-17.

Krishnaiah, D., Sarbatly, R. and Bono, A. 2007. Biotechnology. Molecular Biology Review. 6(1) 97-104.

Kulisic T., Radonic A., Katalinic V., Milos M. 2004. Use of different methods for testing antioxidative activity of oregano essential oil. Food Chemistry. 85:633-40.

Lawal, I. O., Uzokwe, N. E., Ladipo, D. O., Asinwa, I. O. and Igboanugo, A. B. I. 2009. Ethnophytotherapeutic information for the treatment of high blood pressure among the people of Ilugun, Ilugun area of Ogun State, south-west Nigeria. African Journal of Pharmacy and Pharmacology 3(4):222-226.

Liu, S., Stafeer, M. J., Hu, F. B., Giovannucci, E., Rimm, E., Manso, J. E., Hennekens, C. H. and Willet, W. C. 1999. Whole-grain consumption and risk of coronary heart disease: Results from the Nurses' Health 
Study. American Journal of Clinical Nutrition 70:412-419.

Maiza-Benabdesselam, F., Khentache S., Bougoffa, K., Chibane, M., Adach S., Chapeleur. Y., Max, H. and LaurainMattar, D. 2007. Antioxidant activities of alkaloid extracts of two Algerian species of Fumaria: Fumaria capreolata and Fumaria bastardii. Record of Natural Products 1: (2-3) 28-35.

Mann, A. 2011. Biopotency role of culinary spices and herbs and their chemical constituents in health and commonly used spices in Nigerian dishes and snacks. African Journal of Food Science 5(3): 111-124.

Most, M. M. 2004. Estimated phytochemical content of the dietary approach to stop hypertension (DASH) diet is higher than in the control diet. Journal of the American Dietetic Association 104(11):1725-1727.

Nwaogu, L. A., Alisi, C. S. and Ojiako, O. A. 2008. Studies on the nutritional and phytochemical properties of Persea americana Seed. African Journal online 6(1): 155-160.

Ojiako, O. A. and Igwe, C. U. 2008. "The nutritive, anti-nutritive and hepatotoxic properties of Trichosanthes anguina (Snake Tomato) Fruits from Nigeria". Pakistan Journal of Nutrition 7(1): 85-89.

Okwari, O. O., Nneli, R. R. O., Osim, E. E. and Dasofunjo, K. 2013. Preliminary studies on aqueous fruit extract of Xylopia aethiopica obtained in Calabar Nigeria. Australian Journal of Basic and Applied Sciences 7(9): 67-71.

Olusanya, J. O. 2008. Proteins, In: Essentials of food and nutrition. Apex Books Limited, Lagos. pp.13-21.

Omeh, S. O., Onoja, M. I., Ezeja, S. Bassey, Ogbenta G. and Adetayo A.B. 2014. Phytochemical, Nutrient Composition and Serum Lipid Lowering Effect of Xylopia aethiopica Fruit. British Journal of Pharmaceutical Research 4(17): 2096-2105.

Onwuka, G. I. 2005. Food analysis and instrumentation (Theory and Practice). 1st Edition. Naphtali prints, Surulere, Lagos.pp.50-58.

Ordon-Ez, A. A. L., Gomez J. D., Vattuone, M. A., Isla, M. I. 2006.Antioxidant activities of
Sechium edule (Jacq)Swartz extracts. Food Chemistry 97: 452-458.

Orwa, C., Mutua, A. , Kindt, R.., Jamnadass, R. and Simons, A. 2009. Agro-forestry database; a tree reference and selection guide. (http://www.worldagroforestry.org/af/t reedb/).

Pande, P. S., Mane, V. D. and Mishra, M. N. 2014. Evaluation of antioxidant activity of saponin and tannin fractions isolated from the leaves of Tridax procumbens. International Journal of Pharmaceutical and Biological Sciences 5(1):396-400.

Pandy, K. B. and Rizvi, S. I. 2009. Plant polyphenols as dietary antioxidants in human health and disease. Oxidative Medicine and Cellular Longetivity 2:270-278.

Parameswaran, I. and Murthi, V. K. 2014. Comparative study on Physico and phytoChemical analysis of Persea americana and Actinidia deliciosa. International Journal of Scientific and Research Publications 4(5):22503153

Ross, I.A. 1999. Medicinal plants of the world chemical constituents, traditional and modern uses. Totowa, New Jersey: Humana 241-247.

SACN, 2008. Draft SACN position statement in dietary fibre and health and the dietary f $\quad \mathrm{i}$ b $\quad r \quad e$ definition.August2008.SACN/08/20.htt p://www.sacn.gov.uk/pdf/final_draft_sa cnstatement-on-dietray-fibrefor-websitepdf.

Sinha, N. and Dabla, P.K. 2011. Oxidative stress and antioxidants in hypertension - a current review. Current Hypertension Reviews 11(2):132-142.

Sun, J. S., Tsuang, Y. W, Chen, I. J., Huang, W. C., Hang, Y. S. and Lu, F. J. 1998. An ultraweak chemiluminescence study on oxidative stress in rabbits following acute thermal injury. Burns 24: 225-231.

Upadhyay, S. and Dixit, M. 2015. Role of polyphenols and other phytochemicals on molecular signaling. Oxidative Medicine and Cellular Longetivity, Article ID 504253, 15 pages.

Usman, H. and Osuji, J.C. 2007. Phytochemicals and in- vitro antimicrobial assay of the leaf extract of Newbouldia leavis. African 
158 Gbadamosi and Kalejaye: Comparison of the Antioxidant Activity, Phytochemical and Nutritional Contents

journal of Traditional, Complementary and alternative Medicine 4(4): 476-480.

Venkatesh, R. and Sood, D. 2011. Review of the physiological implications of antioxidants in food. Bachelor of Science Interactive Qualifying Project. Worcester Polytechnic Institute, Worcester, Massachusetts, U. S.
Wolfe, K, Wu, X. and Liu, R. H. 2003. Antioxidant activity of apple peels. Journal of Agricultural and Food Chemistry 51: 609-614.

Yasir, M., Das, S. and Kharya, M. D. 2010. The phytochemical and pharmacological profile of Persea americana Mill Pharmacognosis Review 4(7): 77-84. 